\title{
Cooperation, Media and Framing Processes
}

\author{
Insights from a Baltic Sea Case Study
}

\author{
Anna Maria Jönsson \& Mikael Karlsson
}

\begin{abstract}
Cooperation and communication play an important role for environmental governance. This holds true for the Baltic Sea in Northern Europe, one of the most disturbed ecosystems in the world, where insufficient cooperation between different stakeholders is one reason for goal failure. This article addresses the linkages between (media) framing on the one hand, and cooperation on the other. The case in focus is a set of negotiations related to the Baltic Sea Action Plan, the most central governance strategy in the Baltic Sea region. Our results show that in order to influence political decision-making, key stakeholders compete over the power to define and interpret problems, causes and solutions to an extent impeding cooperation. We focus the analysis on eutrophication, which we show to be a complex and controversial topic, framed in incompatible ways by different stakeholders.
\end{abstract}

Keywords: framing, cooperation, Baltic Sea, environmental governance, eutrophication

\section{Introduction}

Cooperation is closely linked to framing and can play an important role in the governance of complex environmental problems. This holds true for the Baltic Sea, one of the most disturbed ecosystems in the world (HELCOM 2010). In spite of awareness of these challenges four decades ago, few of the public objectives have been reached (Gilek et al. 2016). In the Baltic Sea area, institutional structures and processes are far from adequate for coping with the challenges at hand and insufficient cooperation between stakeholders is one key reason for failure to achieve goals (Gilek \& Karlsson 2016).

Successful cooperation often presumes a basic common understanding among stakeholders about problems, causes and potential solutions, or in other words a common framing. This is sometimes also a prerequisite for cooperation to take place at all. Cooperation is also closely related to the ability to communicate, using different platforms and communication media. While a number of studies have analysed how competition among key stakeholders over the framing of problems and solutions in order to influence environmental politics is reflected in media, the linkages between framing and media, on the one hand, and environmental cooperation, on the other, have only been explored 
occasionally (Tynkkynen (2014) is one example). We aim to fill this gap and investigate how key stakeholders in a specific country, Sweden, strive to frame political processes and influence media in the context of Baltic Sea environmental policy, how their actions are perceived by others, and how this may influence cooperation.

The empirical case in focus is a negotiation round in 2012-2013 on the Baltic Sea Action Plan (BSAP) (HELCOM 2007) adopted by HELCOM, the operative body of the Helsinki Convention on the Protection of the Baltic Sea Area $(1974 ; 1992)$. The BSAP is the most central governance strategy in this context and we focus the analysis on the problem of anthropogenic eutrophication caused by nutrient emissions. The consequent effects in the Baltic Sea are severe and include oxygen-free bottom zones and huge algal blooms, which damage biodiversity and socio-economic values (HELCOM 2013a). The main sources of nutrient emissions are well known and include agriculture, sewage water and atmospheric deposition, but uncertainties exist regarding long-term effects and how ecosystems respond to mitigation (Karlsson et al. 2016). A previously contested issue concerned the roles of nitrogen and phosphorus, but a consensus emerged that it is necessary for levels of both nutrients to decrease; today the role of the background load of nutrients is debated (Conley et al. 2009; Karlsson et al. 2016).

The governance efforts concerning eutrophication consist of public and voluntary strategies, and the HELCOM collaboration has for long played a central role. The more specific BSAP targets on eutrophication are based on a decision support model that integrates environmental and economic parameters, the Baltic NEST, developed by scientists (Baltic Nest Institute 2014). When the BSAP was adopted in 2007, however, a number of issues were deferred to be dealt with later on, one being implementation of the eutrophication targets. Consequently, at the following HELCOM Ministerial meeting in 2010, the issue was on the agenda, partly based on reports on plans established by the convention parties (e.g. MOE 2010). The parties agreed "to carry out a review of the [BSAP] environmental targets for eutrophication, the maximum allowable inputs and the nutrient reduction targets, as well as the country-wise nutrient reduction targets ... [and] based on the result of the review, to evaluate the need for additional measures at the 2013 HELCOM Ministerial Meeting”, which took place in Copenhagen. The more specific national implementation decisions have been in the last few years, the more questions have been raised by affected stakeholders (Linke et al. 2016). This turned out to be one of the key contested issues in the negotiation round studied in this paper.

Against this background, this article describes how the development of and debate around the negotiation round are framed in news media, and it analyses how this relates to stakeholders' perceptions, strategies and actions. We further discuss how this in turn may influence the potential for enhanced cooperation, both within national and international contexts. Besides zooming in on eutrophication, we focus on Sweden, in order to see how the situation plays out in a country with a strong track record in environmental policy (Lidskog \& Elander 2000). We examine how that record influences Swedish positions and what that has meant for the negotiations. Our intention is not to study all the factors explaining the international negotiation outcome, but instead to focus on the national context for one of the key players, Sweden. This is motivated by the fact that the Baltic Sea policy debate, despite concerning an international marine environment, is strongly national or local (Jönsson et al. 2016). Nevertheless we see a potential for learning from this selected example. 
More precisely, we will answer the following questions:

- Which BSAP-related positions do the main Swedish stakeholders advocate and how are they potentially trying to push for and frame their viewpoints?

- How is the BSAP framed in Swedish news media and what is identified as problems, causes and solutions? Are there common frames or competing discourses, and how do these relate to the main Swedish stakeholders' intentional framing and claims on knowledge and policy?

- How do these circumstances potentially affect cooperation nationally and internationally?

After this introduction, a section theorising media, cooperation and framing follows. Next, the chosen methods and material are presented. The subsequent two descriptive sections present results, followed by a final analysis and discussion.

\section{Media, cooperation and framing}

\section{Media, politics and cooperation}

Studies on the role of media in relation to politics and governance has generally focused on political elections or certain issues or events and how media contribute to setting agendas and framing issues. Studies of political communication have also extensively addressed how different actors try to influence media agendas and how media affect citizens' opinions and political behaviour (cf. McNair 2011).

Studies on media and (political) cooperation can be found mainly in fields like political communication and international relations. It is pointed out, however, that it is common to study the role of media in conflicts like war and terrorism, and that this probably is at least partly explained by the fact that news media tend to focus on conflicts of different kinds (Wolfsfield 2004). Our study addresses the issue of cooperation as an important part of environmental (national and international) governance and as a prerequisite for an improved environment. Even though there are obvious links to conflicts we also see challenges related to cooperation that are not directly connected with an explicit conflict. We distinguish between cooperation and negotiations and look at prerequisites for cooperation during a particular process of negotiation.

Wolfsfield (2001) sets out to explain why and how media play either a constructive or a destructive role in peace processes (negotiations) and he puts forward four major types of impact that news media can have on peace processes: define the political atmosphere; set the tone of the debate; have an impact on antagonists'strategies and behaviour, and influence the legitimacy of the actors involved. Although this theory focuses on media in relation to governments, we find it useful also for the analysis in our case, and especially in order to understand how media have an impact on stakeholders' strategies and behaviour. Stakeholders' actions are affected by previous media content as well as by strategic moves to influence media content and thereby public debate and public opinion.

In order to analyse how stakeholders in our case try to influence the understanding of problems and solutions, how media reflects that, and how stakeholders are influenced by media content, we have applied the theoretical concepts of framing and frames, and combined perspectives from political sociology with media and communication studies. 


\section{Framing the environment}

In the area of policy-making theory and political sociology, the concept of framing is often used for analysing how actors are involved in debating and setting a particular agenda and furthering its implementation (Rein \& Schön 1993). The way issues are framed reflects particular versions of human relations and human agency, and is thus informative also for questions about the role of different stakeholders and their cooperation. Framing, for example, clearly takes place in the environmental debate regarding the Baltic Sea (cf. Jönsson 2011, Tynkkynen 2014).

In risk policy processes, framing can play a double role by simplifying complexity, which in turn facilitates regulation (Lidskog et al. 2011), and by allowing reflection upon this complexity (Boström \& Klintman 2008). The concept of "frame reflection" denotes the possibility of improving understandings of one's positions (Schön \& Rein 1994), which would also facilitate cooperation. A challenge for policy makers and stakeholders is thus to shape frames that may stimulate perception of several aspects. Frames should attract many stakeholders, and lead towards agreement on problem definitions and risk policies. This is an ideal model - in practice, frames also work to protect actors' own interests.

Media is the main actor for framing problems and solutions on environmental issues in public and political discourse (Allan et al. 2000; Anderson 1997; Hansen 2010). The notion of "framing contests" has been used to direct analytical attention to power aspects of media frames (Gamson \& Modigliani 1989; Miller \& Riechert 2000). Media frames are shaped by competing stakeholders or claim-makers, such as politicians and social movements (Carragee \& Roefs 2004).

In contemporary media studies, the concept of framing consists of two main dimensions; one that refers to the way certain aspects in a text are made more salient (media frames), and one that concerns how frames may affect how people perceive reality (individual frames). In the words of Entman (1993: 52): "to frame is to select some aspects of a perceived reality and make them more salient in a communication text, in such a way as to promote a particular problem definition, casual interpretation, moral evaluation, and/or treatment recommendation for the item described [italics in original]". This is called framing elements in the present study. A frame also suggests what a particular controversy is about, but could moreover work as a tool to construct conflicts and controversies (cf. Gamson \& Modigliani 1989).

Framing is thus a concept that has been applied to a wide range of issues and that has been theorised in several different ways. The research area on environmental news frames is rapidly growing in the field of media studies (cf. Berglez 2011; Boykoff 2007; Eide 2011; Olausson 2009); moreover, there are studies on media framings of environmental issues in relation to the Baltic Sea (cf. Jönsson 2011; Lyytimäki 2007; Tynkkynen 2014). A previous analysis of media framings of the Baltic Sea environment, for example, showed that eutrophication was the risk that received most attention. Agriculture was presented as the main problem, while politically-based restrictions were portrayed as key strategies. Moreover, problems with cooperation and mitigation costs in agriculture were mentioned as key barriers (Jönsson 2011).

Few studies hitherto have linked media framings to stakeholders' actions and positioning with the intention to influence the political process, and the importance this relationship may have for cooperation. 


\section{Method and material}

Intending to identify the main positions and frames in the Swedish public discourse on the BSAP negotiations in 2012-2013, we used a combination of quantitative and qualitative text analysis of the BSAP issue in media in 2012-2013, as well as in reports and position papers collected from the organisations in media focus (i.e. the stakeholders dominating the public media debate in Sweden). Besides these textual analyses we conducted a series of interviews with key stakeholders.

The media study was focused on Swedish print media, including newspapers (local and national) as well as journals and magazines from authorities and organisations. The debate was also present in broadcast media, mainly in webnews, and it was very similar to that in newspaper media, since it used much the same sources etc. For practical reasons, we chose to limit the in-depth media analysis to newspapers. We did however also look into the material from radio and television media and will comment on important differences when called for. To find relevant articles for our analysis we used the search engine "Retriever". One methodological challenge was to find keywords that really identified relevant articles but after using a number of combinations we concluded that the keywords "Helcom" and "BSAP Baltic Sea" in different combinations were useful. In the analysis, we scanned and selected all the articles that met these keywords and the issue at hand.

There is no consensus on how to identify frames in news and other texts. In this study we first identified framing dimensions defined as topics, sources and mechanisms (cf. D'Angelo \& Kuypers 2010) and drew conclusions on main frames and actors. In the next step we looked into the presence and functions of predefined generic frames (cf. de Vreese 2005; Matthes 2009). In this case we chose conflict, human interest, economy and attribution of responsibility ${ }^{1}$ as most relevant, using a deductive approach in the analysis. Generic frames are often used for comparative reasons (cf. Carvalho 2007; Semetko \& Valkenburg 2000) and we consider them relevant for an extended discussion on the relation between framing and cooperation in different cases. We did not compare countries but looked at different written news media. We also analysed framing elements, meaning how problems, causes and solutions were presented (Entman 1993). The framing elements show us how the generic frames are constructed. Based on these we analysed possible framing effects on cooperation. As a way to understand the relations between stakeholder action and media frames we also discussed frame building processes and how internal and external pressures affect framing (cf. Cooper 2002).

We conducted both a general and a specific analysis. The former was based on the broader selection of Swedish media and the mentioned communication material (i.e., news media texts as well as publications from NGOs and other organisations, political organs, authorities etc.). We analysed all identified articles, 124 in total. The material was studied by using a text analysis guide, which helped us inductively to identify issue-specific frame dimensions and elements (topics, sources, main problems, causes and solutions), mainly by looking at headlines, introductions, concepts used and actors' positions in the text. We followed Entman (1993:52) who suggested that frames in the news can be examined and identified by "the presence or absence of certain keywords, stock phrases, stereotyped images, sources of information and sentences that provide thematically reinforcing clusters of facts or judgments". We then also conducted a deductive analysis looking for generic frames, following de Vreese (2005) and Semetko $\&$ Valkenburg (2000). The analysis was restricted to text and did not include images. 
Images do contribute to framing but we concluded that we did not need these to answer our questions. In order to understand the frame building process, mechanisms and framing elements, we also conducted a closer analysis of three articles published in Dagens Nyheter and Aftonbladet (two of the biggest national newspapers in Sweden). The reason for choosing these articles is that they occur in newspapers with a large readership. The articles also represent three typical articles in this media discourse and are of enough volume to work as illustrations of the relation between media and stakeholders.

In addition to the media and document analysis, three key stakeholders (four individuals) were interviewed: two from a national environmental NGO, which was also internationally active in the region in focus, one from a national and international part of the business community, and one from the governmental side (a civil servant). The interviewees were selected from among the key Swedish stakeholders and participants in the debate and the negotiations at the current time, from the governmental side and from the environmental and business spheres. The interviews were conducted in the first half of 2015; they were semi-structured and lasted from one to one and a half hours. The key themes concerned positions advocated (mainly in relation to our frame elements, as described above), framing strategies, the view on media and on other stakeholders' positions and activities, and reflections on cooperation and governance.

The study thereby included actors' intentional framings as well as media outcomes and stakeholders' perceptions of frames. Using these methods and empirical material we were able to identify positions, strategies and frames in the Swedish public discourse and among some of the dominating actors. Based on this we drew conclusions on possible implications for cooperation and if the media played predominantly a constructive or destructive role.

While our empirical material only includes Sweden, the outcome of the negotiations and possible success of cooperation also depends on positions and strategies from actors in other countries. Stakeholders cooperate nationally as well as internationally. The results also depend on the choice of environmental problem in focus - in this case eutrophication - and that problem's particular contexts. We do however argue that by analysing the relation between actors' positions and media framing and the actual framing processes in Sweden we learn about important elements in (environmental) cooperation and the role of the media, even though the media landscape and the relation between media and different actors differ between the Baltic Sea countries.

The following sections present our empirical analysis. We start with a presentation of the BSAP-related positions that the main Swedish stakeholders advocated and the framing strategies used.

\section{Positions and communication related to the ministerial negotiation round}

The preparatory process of the 2013 Ministerial started in June 2012. A draft report on potentially revising the BSAP eutrophication targets was presented by HELCOM at a meeting of the Heads of Delegations (HOD) (TARGREV 2012), in which stakeholders participated. The parties then agreed on a plan for preparing the Ministerial (HELCOM 2012a).

A preliminary draft declaration came at the next HOD meeting, but many delegations were not ready to discuss it. Our respondents clearly state that business interests and 
environmental NGOs were highly active, though, which for instance led to some adjustments in the model on effort sharing. In November, the parties discussed substance issues and the NGO Coalition Clean Baltic (CCB) gave oral input (HELCOM 2012b). A more thorough first draft was published in the beginning of 2013, and was discussed at both a HOD and a HELCOM meeting in March, at which CCB again added comments, also in writing (CCB 2013). CCB proposed that the Ministerial should agree on additional mandatory requirements for nutrient management.

Until then, farmers' organisations had not participated. However, the Federation of Swedish Farmers (LRF) had presented a text for the Swedish Environment Minister back in September 2012, arguing that the targets on eutrophication were impossible to reach, due to high background load and long environmental repair processes (LRF 2012). In addition, LRF (2013) sent a consultation paper to all stakeholders and argued that the targets were too high and the background loads not considered, and that national politics should be more influential. According to our respondents, this paper brought the controversies into the political sphere and fuelled debate, including debate between the environment and agriculture ministries, despite their respective ministers being of the same party. WWF Sweden and others responded with criticism (WWF 2013a).

A second draft in May (HELCOM 2013b) and a third draft in June (HELCOM 2013c) gradually became more precise, including on the issue of eutrophication. In parallel, stakeholders increased their efforts in terms of lobbying both the HODs and governments and on the public stage, where media played an important role, according to our respondents. They all clearly stated that neither the farmers' nor environmental organisations were satisfied with the Swedish government's positions. WWF Sweden presented - just before the agenda-setting "Almedalen Week" in Sweden ${ }^{2}$ - a larger assessment of the state of the Baltic Sea, including a critical analysis of governance efforts (WWF 2013b). Similarly, the view of LRF that targets were unreasonable was echoed in the debate. When the time for the October Ministerial approached, stakeholders published press releases that reflected their positions, directed towards the negotiating politicians. These advocacy efforts also led to debates in the Swedish Parliament (Environment Committee 2013; Interpellation Holm-Ek 2013).

In the governmental process it became increasingly clear that some nations had problems with various concrete proposals. Regarding eutrophication, and due to pressure from the farmers, the Swedish government questioned the entire basis for calculating national responsibilities to decrease nutrient emissions (HELCOM 2013d). This caused criticism from environmental NGOs and some countries, not least Denmark, the host for the Ministerial. The new Swedish position became difficult to defend, even in the eyes of the environment minister, according to our respondents. Sweden thus agreed on the modelling, but still managed to soften the language on compulsory measures for farmers (HELCOM 2013e).

Afterwards, environmental and farmers' organisations took critical but opposing views on the outcome of the BSAP revision, according to our respondents. Judging from them, the decisions on measures against nutrient leakage were one of the most critical components in the negotiations and the dispute was far from resolved.

We now move on to the question of how the BSAP was framed in Swedish news media and how these framings related to the main stakeholders' intentional framing and claims on knowledge and policy. 


\section{Framings of the BSAP negotiation process}

\section{Mapping the discourse}

Swedish printed media published a total of 124 articles about the Ministerial negotiation round in 2013. These 124 articles were spread across almost 50 different publications and most media only published one or two articles on the theme. About 95 per cent of the articles were published in newspapers (local and national). There was also a clear pattern that the reporting about BSAP and this case mainly came out in July and October 2013 (about 80 per cent) (Figure 1) and that this was closely linked to the events and actions taken by the key stakeholders. ${ }^{3}$

In July, WWF presented a report (WWF 2013b) that criticised Baltic Sea governance and showed that the BSAP goals were not reached. All countries, and especially Russia, were said to have failed in more or less all areas, with measures against eutrophication taken by Finland and Germany as possible exceptions. The report was acknowledged in general news media, as well as in print and online forums for different organisations and authorities. ${ }^{4}$ The relatively high visibility was probably due to WWF being judged a credible sender. More or less all articles were re-writings of the WWF press release. As noted above, the report was presented just before the "Almedalen Week" in Sweden, during which attention to Baltic Sea issues is often high.

The next peak for the BSAP issue, in the beginning of October 2013, related to the Ministerial meeting taking place. This event was more closely linked to the journalistic discourse and the media worked actively with their own journalists, contributing with their own frames.

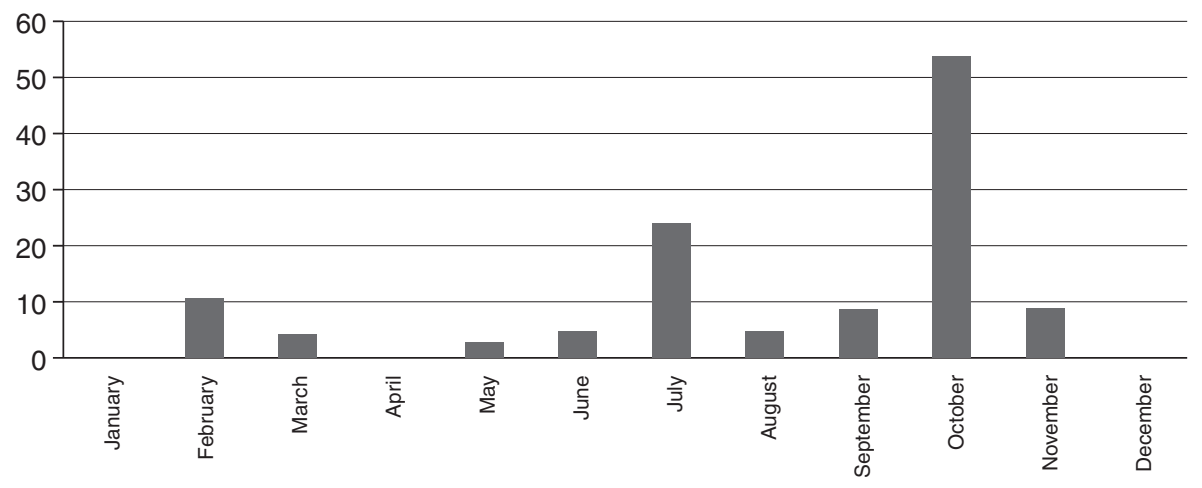

Figure 1. Number of articles about BSAP in Swedish media in 2013

If we consider the numbers of printed media articles, however, the mediated discourse mainly took place outside the mainstream national media discourse, i.e., in local media and special interest media. These were local newspapers in the south of Sweden and close to the Baltic Sea, or journals and other documents published by NGOs and other organisations. These are not the main agenda-setting media on the national arena but may be important for specific groups. Some of the local newspapers have the same owner or are part of a consortium, meaning that they sometimes publish the same material. Hence, not all of the 124 articles were unique. These newspapers also to a large extent used the same sources (mainly TT and SMHI) resulting in much the same frames and 
perspectives. Overall the news media presented a very similar picture of the negotiations and the Ministerial meeting. In the interviews our respondents stated that the BSAP negotiations were seldom a topic for national debate. However, they also claimed that the debate that took place had obvious political implications in, for example, the government, including between ministries. This shows that it was not the amount of reporting that was decisive in this case.

The main stakeholders involved in the actual negotiations were also highly visible in the media discourse and central in the frame building processes (influencing the construction of frames), in line with what they strived for, according to the respondents, albeit not to the extent considered desirable. As for stakeholders' influence on framing and the degree of success in positioning themselves, there was certainly a difference between different media genres. Editorials, for example, are the voice of the media and journalists while opinion pieces express views from stakeholders and elite actors, such as politicians, scientists and larger NGOs. Letters-to-the-editor, on the other hand, are generally presenting the voice of the citizens. In this case, news articles, editorials and opinion pieces dominated the media discourse while active voices of citizens through letters-to-the-editor were rare. Previous research also shows that citizens' voices are often missing in mediated discourses on environment (Egan Sjölander \& Jönsson 2012).

\section{Media framings - dimensions and elements}

The main topic in the BSAP media discourse in 2013 was "eutrophication", where the risk was presented as mainly caused by humans, foremost agriculture, and where restrictive actions were seen as needed. Eutrophication is also closely related to the problem of algal blooming, which is one of the most newsworthy among environmental risks, since it is comparatively easy to illustrate, and because the audience can easily identify itself with the problem (cf. Jönsson 2011). One respondent said this was a problematic simplification of the situation.

Looking at the generic frames, the attribution of the responsibility frame was highly visible in the whole material and concerned the role and responsibility of politics and regulation in relation to voluntary action. The conflict frame was also common (often in the same article as the attribution of the responsibility frame), not least represented by LRF in media, in attempts to downplay the role of agriculture and to focus on other measures. LRF's arguments were also closely related to an economic frame, with a focus on how actions can and will cause economic problems. It is also obvious that there was a kind of "us against them" dimension in the Swedish news media discourse in this case, with Poland, Russia and the Baltic States regularly being portrayed as the troublemakers and therefore framed as part of the problem. The European Union, on the other hand, was often presented as an institution through which it would be possible to improve cooperation and coordination. To present the issue as a conflict between different interests can be seen as a framing mechanism. There were not many examples of the human interest frame in this discourse and the individual perspective was clearly not in focus.

According to Entman (1993), it is important to analyse how media work to promote a particular problem definition and solution recommendation in order to understand how a certain issue is perceived and acted upon. In our study it was interesting to analyse which stakeholders' positions and ideas were represented in the media discourses. In 
2013, the main stakeholders were politicians, experts and representatives from different NGOs (mainly LRF and WWF), all being actors who can be regarded as central in the frame building processes.

In order to understand the frame building process and framing elements in terms of representations of problems, causes and solutions, we next provide a closer analysis of three articles published in Dagens Nyheter (national broadsheet, liberal) and Aftonbladet (national tabloid, social democratic) during 2013. As noted earlier, the reporting about BSAP and the Ministerial was scarce in national newspapers. In 2013 there were only two articles in Dagens Nyheter and one in the tabloid Aftonbladet about the issue. As a comparison, we studied the media discourse in 2012 and 2014 to see if the 2013 Ministerial changed the debate, and if so how. Moreover, in 2014 the BSAP was not present at all in the studied Swedish media.

The first article in Dagens Nyheter in June was an editorial (presented as part of a cluster of articles around the theme "Will the Baltic Sea survive?") ${ }^{5}$ with the headline "Utopian demands for the Baltic Sea". ${ }^{6}$ The article was published shortly after the presentation of the third draft declaration, and after the LRF consultation paper, and took as its starting point the claim that stricter regulations on phosphorus emissions were to be decided at the Ministerial. The choice of wording in the headline - utopian - is important for the framing that there was huge uncertainty regarding the solutions, and that the goals and tools were more or less unrealistic. "Twice as much phosphorus has to go. But how? Nobody knows, and few dare to say that it is impossible". The journalist claimed that neither science nor politicians can solve the problem with phosphorus in the near future and that the problem mainly was caused by past sins (part of the sediments today). Therefore, less responsibility should be placed on the agricultural sector. According to the journalist, the agricultural sector is unfairly seen as something of a scapegoat for eutrophication. The stakeholder from the business side interviewed for this study was clearly very positive about this article, whereas the environmental NGO respondents found it problematic. The civil servant interviewed stated that this article made a substantial impression in the internal governmental debate.

Dagens Nyheter also published one regular news article in October 2013, just before the ministerial. The article, with the headline "Criticism against Sweden before Baltic Sea meeting"7 focused more or less entirely on eutrophication, and already in the beginning a conflict was presented. "Eutrophication is threatening the Baltic Sea. This Thursday environmental ministers from the Baltic Sea countries meet to come to an agreement about emission quotas. But several environmental organisations are sceptical and are now criticising Sweden for slowing down the process around emissions from agriculture." The article reported that the Swedish government had been criticised for lagging behind some other countries (using voluntary measures rather than binding rules) and quoted an expert at WWF Sweden who represented this strand of criticism. The environmental minister at the time, Lena Ek, was allowed to make her voice heard and she claimed that she did not understand the criticism. The stakeholders obviously did not share the same problem frame, which was also confirmed in the interviews. According to Ek, one of the main challenges at the Ministerial was how to get countries like Poland and Russia on board. The article presented as a fact that establishing national emission quotas for nitrogen and phosphorus was one of the most important issues, and that agriculture bore the main responsibility. Poland and Russia were also 
identified as part of the problem. This followed a common pattern in Swedish public discourse on international relations that Russia is a threat. The article used an overall dramatised discourse with colourful language that framed the issue, for example: "The cod is fighting for its survival and sea beds are dying".

The tabloid Aftonbladet published only one article, in July 2013, in the form of an opinion piece with the headline "Sweden is betraying its promise to fight algal blooming". ${ }^{8}$ It was written by WWF Secretary General Håkan Wirtén, and WWF Baltic Sea expert Lennart Gladh, and was an extension of the WWF study at the same time, arguing for stricter measures. The problem issues discussed were eutrophication and algal blooms, caused mainly by phosphorus (but nitrogen was also pointed out as source) and imposing health risks on humans and animals. Agriculture was framed as the main problem. The timing is evidently part of the framing process since algal blooming is a typical news theme in Sweden during July: "Algal blooming arises when seas and lakes are over-fertilised. Emissions from agriculture are often the single biggest villain." The article also indirectly criticises politicians who, according to the authors, only adhere to "inadequate measures". Politicians are framed as responsible for the solutions and the Ministerial meeting as the place and the time when politicians should shoulder their responsibility.

In general, the respondents were not satisfied with the media coverage of the BSAP process and did not consider all the frames to be "theirs". As late as in 2015, the interviews clearly indicated a high level of irritation on the other side, albeit this criticism focused on substantive issues rather than on specific persons. There was a high level of "understanding of the role" that others were taking, but seemingly still far from a desirable situation for setting up cooperative processes. When asked if the media coverage and debate was beneficial for the societal dialogue on the topic, and if it enabled frame reflection and a better understanding of other perspectives, the respondents generally considered the debate to obstruct rather than promote collaboration, which they all saw as important in order to improve governance, irrespective of their differing viewpoints on what that means in practice.

\section{Conclusions and discussion}

Framing and communication are central for the governance of complex environmental issues. In this case study on a debate that mainly came to concern eutrophication in the Baltic Sea, we see that media played an important role in Sweden for public communication of the problems and potential solutions at hand, both during the preparatory negotiations on the revision of the BSAP and at the time of the Ministerial meeting in October 2013. We also see that several key stakeholders participated actively in the Swedish public discourse and managed to influence the Swedish media coverage, even though we also acknowledge that each of them expected a greater impact. It is additionally clear that various stakeholders, like environmental NGOs and farmers' organisations, deliberately tried to influence the frame building process and "use" media in order to communicate their own analysis of the situation and the positions they advocated themselves. This concerned both problem definitions and the policy outcomes they considered desirable. Moreover, the existing scientific uncertainties communicated by scientists and the disagreements communicated by stakeholders opened the way for positioning and debate. 
In this "context of uncertainty", both environmental NGOs and farmers' organisations were able to place their own agendas on the public stage, although it was commonly done in different media and on different occasions. In Baltic eutrophication policy the pendulum has thus swung back towards conflict, after a period of more or less consensus (Karlsson et al. 2016). These views held by stakeholders on key issues and the disputes in the BSAP negotiations were furthermore framed in the media discourse in the desired way, according to the stakeholders, albeit not with the desired volume. All in all, organisations were at least somewhat successful in their campaigns, to judge from the fact that the limited media coverage, together with other measures taken by stakeholders, did lead to a wanted political debate. In addition, it is clear in the study that the Swedish societal debate, including in media, had an impact on the outcome of the Swedish preparatory process and also on the international negotiations, where the Swedish government's manoeuvring led to international reactions and counteracting policy proposals from other countries, albeit the details in this political game remains to be detailed more closely in forthcoming studies. It is nevertheless evident that individual organisations in individual countries can play a significant role in international policy processes.

Regarding the impact of the media debate on the potential to cooperate on governance issues, both between various stakeholder groups and between the different politicians who engage themselves on different sides in the process, we can conclude that the situation is problematic. The media debate with its preference for conflict framings obviously contributed to paint a more negative picture of "the others" and led to increased irritation and confusion, rather than to understanding and recognition of other perspectives and viewpoints. Our study, as well as previous research, shows that controversies often in themselves are paths to publicity, and we can thus see a negative spiral where media publicity fosters conflict rather than consensus and cooperation. Media also tend to reduce complexity; something that would decrease the possibilities for them to contribute to actors' frame reflection. Based on these conclusions, a rather gloomy picture emerges in relation to our starting point that cooperation is pivotal for environmental governance, and that successful cooperation ought to be based on at least a basic common understanding about the problems at hand, as well as their causes and potential solutions.

If the debate in a single country with a large number of shared media - a situation that, according to Wolfsfield (2004), would mean a more constructive role for the media in negotiation processes - and with comparatively strong environmental ambitions, cannot foster a larger common "framing denominator" than we saw in this study, it is difficult to see how an international debate could be more fruitful at present. Linking this to previous studies on Baltic Sea environmental governance (Gilek \& Karlsson 2016), we see a need for institutional initiatives that again can help building a strong sciencebased picture of problems and potential measures relating to eutrophication. While we of course cannot prejudge how that would impact on framing exercises, media and cooperation, we still consider it would be helpful when aiming for the internationally agreed BSAP objectives. Moreover, and in particular if the media debate were to be contested in countries around the Baltic Sea, it also seems important to develop international forums for dialogue, where stakeholders such as environmental NGOs, farmers and other business representatives can meet together with scientists and governmental policymakers, in order to build mutual trust and seek the largest common denominator on world-views and strategies from multiple governance perspectives. Similar arrange- 
ments for scientific consensus building and societal dialogue might be worth striving for as complementary strategies in completely different areas of complex environmental issues, where stakeholder framing attempts and contested media debates are not proving fruitful enough in relation to the need for cooperation on environmental governance.

\section{Notes}

1. Conflict: journalistic practice of reporting stories of conflicting interpretation; human interest: brings a human face or an individual's story to the presentation of an event/issue; economy: focus on profit and loss; responsibility: presents an issue in a way that attributes responsibility for causing or soling to a particular group of actors (cf. de Vreese, 2005).

2. During this annual event in July, thousands of politicians and stakeholders gather in Visby in Sweden for thousands of seminars, see http://www.almedalsveckan.info/6881.

3. This is also the case with the reporting in Swedish radio and television.

4. WWF was also one of the main actors in broadcasting news media.

5. 'Överlever Östersjön?', Dagens Nyheter.

6. 'Utopiska krav för Östersjön', Dagens Nyheter, 2013-06-11.

7. 'Sverigekritik inför Östersjömöte', Dagens Nyheter 2013-10-01.

8. 'WWF: Sverige sviker löfte att bekämpa algblomningen', Aftonbladet, 2013-07-16.

\section{References}

Allan, Stuart; Adam, Barbara \& Carter, Cynthia (2000). Introduction: The media politics of environmental risks. pp. 1-26 in Allan, Stuart; Adam, Barbara \& Carter, Cynthia (eds.) Environmental risks and the media. London: UCL.

Anderson, Alison (1997). Media culture and the environment. London: Routledge.

Baltic Nest Institute (2014). Baltic Nest Institute. http://www.balticnest.org. (accessed 24 November 2014).

Berglez, Peter (2011). Inside, outside, and beyond media logic: Journalistic creativity in climate reporting. Media, Culture \& Society, 33(3): 449-465.

Boström, Magnus \& Klintman, Mikael (2008). Eco-standards, product labelling and green consumerism. Basingstoke: Palgrave Macmillan.

Boykoff, Maxwell T. (2007). From convergence to contention: United States mass media representations of anthropogenic climate change science. Transactions of the Institute of British Geographers, 32(4): 477-489.

Carragee, Kevin \& Roefs, Wim (2004). The neglect of power in recent framing research. Journal of Communication, 54: 214-233.

Carvalho, Anabela (2007). Ideological cultures and media discourses on scientific knowledge: re-reading news on climate change. Public Understanding of Science, 16(2): 223-243.

CCB (2013). CCB proposals for the HELCOM Ministerial Declaration, October 2013. CCB position paper, 15 February 2013. Uppsala: CCB.

Conley, Daniel J.; Paerl, Hans W.; Howarth, Robert W.; Boesch, Donald F.; Seitzinger, Sybil P.; Havens, Karl E.; Lancelot, Christiane \& Likens, Gene E. (2009). Controlling eutrophication: nitrogen and phosphorus. Science, 323(5917): 1014-1015.

Cooper, Alice Holmes (2002). Media framing and social movement mobilization: German peace protest against INF missiles, the Gulf War, and NATO peace enforcement in Bosnia. European Journal of Political Research, 41(1): 37-80.

D’Angelo, Paul \& Kuypers, Jim A. (eds.) (2010). Doing news framing analysis: Empirical and theoretical perspectives. London: Routledge.

de Vreese, Claes H. (2005). News framing: Theory and typology. Information design journal+ document design, 13(1): 51-62.

Egan Sjölander, Annika \& Jönsson, Anna Maria. (2012). Contested Ethanol Dreams. Public participation in environmental news, pp. 47-72. in Philips, Louise; Carvalho, Anabela \& Doyle, Julie (eds.) Citizen Voices, Performing Public Participation in Science and Environment Communication. ECREA book series. Bristol: Intellect.

Eide, Elisabeth \& Ytterstad, Andreas (2011). The tainted hero: Frames of domestication in Norwegian press representation of the Bali climate summit. The International Journal of Press/Politics, 16(1): 50-74.

Entman, Robert M. (1993). Framing: toward clarification of a fractured paradigm. Journal of Communication, 43(4): 51-58. 
Environment Committee (2013). Miljö- och jordbruksutskottets betänkande 2013/14:MJU8. Vattenvård. Sveriges Riksdag. [Report 2013/14:MJU8 of the Environment and Agricultural Committee. Water Management. The Swedish Parliament.]

Gamson, William A. \& Modigliani, Andre (1989). Media discourse and public opinion on nuclear power: A constructionist approach. American Journal of Sociology, 95(1): 1-37.

Gilek, Michael \& Karlsson, Mikael (2016). Seeking Pathways Towards Improved Environmental Governance of the Baltic Sea. pp. 228-246 in Gilek, Michael; Karlsson, Mikael; Linke, Sebastian \& Smolarz, Katarzyna (eds.) Environmental Governance of the Baltic Sea. Dordrecht: Springer.

Gilek, Michael; Karlsson, Mikael; Linke, Sebastian \& Smolarz, Katarzyna (eds.) (2016). Environmental Governance of the Baltic Sea. Dordrecht: Springer.

Hansen, Anders (2010). Environment, media and communication. London: Routledge.

HELCOM (2007). BSAP. Adopted at HELCOM Ministerial Meeting, Krakow, Poland 15 November 2007.

HELCOM (2010). Ecosystem health of the Baltic Sea 2003-2007: HELCOM initial holistic assessment. Baltic Sea Environmental Proceedings No. 122. Helsinki: HELCOM.

HELCOM (2012a). Minutes of the HELCOM Heads of Delegation 37th Meeting. Trelleborg, 14-15 June 2012.

HELCOM (2012b). Minutes of the HELCOM Heads of Delegation $38^{\text {th }}$ Meeting. Copenhagen, Denmark, 9 November 2012.

HELCOM (2013a). Approaches and methods for eutrophication target setting in the Baltic Sea region. Baltic Sea Environmental Proceedings No. 133. Helsinki: HELCOM.

HELCOM (2013b). Second draft of the 2013 HELCOM Ministerial Declaration. Response Group $17^{\text {th }}$ Meeting, Klaipeda, Lithuania, 28-30 May 2013.

HELCOM (2013c). Third draft of the 2013 HELCOM Ministerial Declaration. Minutes of the HELCOM Heads of Delegation 41 ${ }^{\text {st }}$ Meeting. Helsinki, Finland, 17-18 June 2013.

HELCOM (2013d). Revised fourth DRAFT. 2013 HELCOM Ministerial Declaration. Undated Negotiation Paper.

HELCOM (2013e). HELCOM Copenhagen Ministerial Declaration. Taking Further Action to Implement the BSAP - Reaching Good Environmental Status for a Healthy Baltic Sea. 3 October 2013, Copenhagen, Denmark.

Helsinki Convention $(1974 ; 1992)$. Convention on the protection of the marine environment of the Baltic Sea Area, 1974; 1992.

Interpellation Holm-Ek (2013). 6§ Svar på interpellation av Holm (2013/14:9) om HELCOM. Anf. 26 Miljöminister Ek (C). Riksdagens protokoll 2013/14:14. 17 oktober 2014. [6§ Response to question by Holm (2013/14:9) regarding HELCOM. Address. 26 Environment Minister Ek (C). The Protocol of the Parliament 2013/14:14. 17 October 2014.]

Jönsson, Anna Maria (2011). Framing Environmental Risks in the Baltic Sea: A News Media Analysis. Ambio 40(2): 121 .

Jönsson, Anna Maria; Boström, Magnus; Dreyer, Marion \& Söderström, Sara (2016). Risk Communication and the Role of the Public: Towards Inclusive Environmental Governance of the Baltic Sea?, pp. 205229 in Gilek, Michael; Karlsson, Mikael; Linke, Sebastian \& Smolarz, Katarzyna (eds.) Environmental Governance of the Baltic Sea. Dordrecht: Springer.

Karlsson, Mikael; Gilek, Michael \& Lundberg, Cecilia (2016). Eutrophication and the Ecosystem Approach to Management: a case study of Baltic Sea environmental governance. pp. 21-45 in Gilek, Michael; Karlsson, Mikael; Linke, Sebastian \& Smolarz, Katarzyna (eds.) Environmental Governance of the Baltic Sea. Dordrecht: Springer.

Lidskog, Rolf \& Elander, Ingemar (2000). After Rio: Urban planning and environmental policy in Sweden. pp 197-218 in Low, Nicholas; Gleeson, Brendan; Elanders, Ingemar \& Lidskog, Rolf (eds.) Consuming Cities: The Urban Environment in the Global Economy after the Rio Declaration. London: Routledge.

Lidskog, Rolf; Uggla, Ylva \& Soneryd, Linda (2011). Making transboundary risks governable: Reducing complexity, constructing spatial identity, and ascribing capabilities. Ambio, 40(2): 111-120.

Linke, Sebastian; Gilek, Michael \& Karlsson, Mikael (2016). Science-Policy Interfaces and Baltic Sea Environmental Governance: towards regional cooperation and coping with uncertainty?, pp. 173-205 in Gilek, Michael; Karlsson, Mikael; Linke, Sebastian \& Smolarz, Katarzyna (eds.) Environmental Governance of the Baltic Sea. Dordrecht: Springer.

LRF (2013). Hur återställer vi Östersjön? Effektivare strategier för ett mindre övergött hav. Remissversion 21 maj 2013. [How can we restore the Baltic Sea? More effective strategies for a eutrophicated sea. Referral, 21 May 2013.] Stockholm: LRF.

LRF (2012). LRF:s syn på Östersjöns övergödning och BSAP. [The view of LRF on eutrophication in the Baltic Sea and on the BSAP.] 9 July 2012. Stockholm: LRF.

Lyytimäki, Jari M. (2007). Temporalities and environmental reporting: press news on eutrophication in Finland. Environmental Sciences, 4(1): 41-51. 
Matthes, Jörg (2009). What's in a frame? A content analysis of media framing studies in the world's leading communication journals, 1990-2005. Journalism \& Mass Communication Quarterly, 86(2): 349-367.

McNair, Brian (2011). An introduction to political communication. Abingdon, UK: Taylor \& Francis.

Miller, Mark M. \& Riechert, Bonnie Parnell (2000). Interest group strategies and journalistic norms. pp. 45-44 in Allan, Stuart; Adam, Barbara \& Carter, Cynthia (eds.) Environmental risks and the media. London: UCL.

MOE (2010). Proposal for Sweden's National Implementation Plan for the BSAP. Stockholm: Ministry of Environment (MOE).

Olausson, Ulrika (2009). Global warming - global responsibility? Media frames of collective action and scientific certainty. Public Understanding of Science, 18(4): 421-436.

Rein, Martin \& Schön, Donald A. (1993). Reframing policy discourse. pp.145-167 in, Fisher, Frank \& Forester, John (eds.) The argumentative turn in policy analysis, planning. London: Duke University Press.

Schön, Donald \& Rein, Martin (1994). Frame Reflection: Toward the Resolution of Intractable Policy Controversies. New York: Basic Books.

Semetko, Holi A. \& Valkenburg, Patti M. (2000). Framing European politics: A content analysis of press and television news. Journal of communication, 50(2), 93-109.

TARGREV (2012). Approaches and methods for eutrophication target setting in the Baltic Sea region. HELCOM Draft. HOD 37. Trelleborg, 14-15 June 2012.

Tynkkynen, Nina (2014). Russia and the Baltic Sea: frames and spaces of environmental problems. Eurasian Geography and Economics, 55(6): 674-690.

Wolfsfeld, Gabi (2004). Media and the Path to Peace. Cambridge: Cambridge University Press.

WWF (2013a). Synpunkter på LRF:s förslag till ny Östersjöpolitik. [Comments to the proposal by LRF on a new policy for the Baltic Sea.] Stockholm: WWF.

WWF (2013b). BSAP - is it on track? WWF Baltic Eco Region Programme. Stockholm: WWF. 